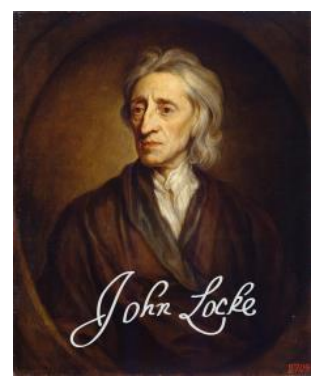

LOCKE STUDIES

Vol. 16

https://doi.org/10.5206/ls.2016.642 | ISSN: 1476-0290

Originally published: 2016

Published online: 10 FEBRUARY 2018

(C) Locke Studies, 2016

\title{
The Wider World of Locke's Landlady Rasby Smithsby
}

\author{
BRIDGET CLARKE (ST. JOHN'S WOOD, LONDON)
}

Recommended citation:

Clarke, Bridget. "The Wider World of Locke's Landlady Rasby Smithsby." Locke Studies 16 (2016): 195213. https://doi.org/10.5206/ls.2016.642

For more information about this article:

https://ojs.lib.uwo.ca/index.php/locke/article/view/642

Locke Studies is published by The John Locke Society.

This is an open access article published under the terms of the Creative Commons AttributionNonCommercial-ShareAlike 4.0 International license, which permits use, distribution and reproduction in any medium, provided the original work is properly cited and shared under the original license. 


\title{
THE WIDER WORLD OF LOCKE'S LANDLADY, RABSY SMITHSBY
}

\author{
BRIDGET CLARKE
}

\section{Abstract:}

This essay explores the life and family of Rabsy Smithsby, Locke's accomplice while he was in Holland and his landlady in London, showing her connections with both the Royal Household and the Cromwell family as well as with Locke and his friends, and with leading merchants and adventurers of her era, as well as noting her surprisingly modern career as 'personal shopper' and bank account owner.

After John Locke's exile in Holland ended in 1689, he lived for the next two years at Mrs. Rabsy Smithsby's house at the first door on the left hand in Dorset Court, Channel Row, Westminster, renting an apartment for $£ 510$ s a quarter. Dorset Court was 'a very handsome open Place, containing but six Houses, which are large and well built, fit for Gentry to dwell in; of which those towards the Thames have Gardens towards the Water Side very pleasant'. ${ }^{1}$ Locke's friendship with Mrs. Smithsby went back many years ${ }^{2}$ - but who was she?

Her father was William Smithsby, ${ }^{3}$ a man who served the Royal family all his life, originally being barber to James VI and I. He was paid 'After King James' death $£ 382$ in full satisfaction

${ }^{1}$ Dorset Court had been built after 1680 by Maurice Emmett on the site of Dorset House, destroyed in the Great Fire. See John Strype, Survey of the Cities of London and Westminster (2 vols., London, 1720), i, 63.

${ }^{2}$ Roger Woolhouse suggests that her sister Anne had been employed as a domestic at Exeter House by Lord Shaftesbury, and that Locke could have met the Smithsbys there. Roger Woolhouse, Locke: A Biography (Cambridge, 2007), 197.

${ }^{3}$ His father was William of Melton Mowbray who married Ursula Brown (d. May 1617) and whose children were William, Thomas, Elizabeth (married Thomas Deeperip 1617), Jane, Joyce, (m. Howell) Anne (m. Goodwynne) and Nicholas, baptised 23 Oct 1597. Will April 1620. 
of all debts due to him' ${ }^{4}$ He had married Rabsey (Cromwell alias Williams of Huntingdon) $)^{5}$ on 1 August 1622 by license at St. Mary le Strand and they eventually had a large family, including Richard, George, ${ }^{6}$ Martha, ${ }^{7}$ Ursula, Judith, Anne, Maria and Rabsy (b. 1640). He became Keeper of the Privy Lodgings and Standing Wardrobe ${ }^{8}$ within the honour of Hampton Court by letters patent, and by 1628 had moved there, as a certificate of residence shows him to be liable for taxation in the Royal Household and not in his previous area, a hundred of Hertford. ${ }^{9}$ In 1635 Charles I, a supporter of Tradescant's museum, ordered 'Keeper of Hampton Court Wardrobe William Smithsby to deliver unto John Tredeskyn (Tradescant) various items of royal clothing for his museum including King Henry the Eighth his capp, his hawking bagg and spurs'.

Her mother Rabsey was a descendant of Sir Richard Williams alias Cromwell(1502-1544), a Welsh soldier whose mother was Katherine Cromwell, sister of Thomas Cromwell. Williams came to court and profited from the dissolution of the monasteries, making a fortune and buying estates, and, following Henry VII's recommendation to the Welsh to take a family name, he took Cromwell's. He was not affected by the fall of Cromwell, however, and in 1543 was made a gentleman of the Privy

4 Issues of the Exchequer 25 May 1627: 'William Smithsby, barber to the late King James, for necessaries for his Majesty’s use $£ 382$ in full satisfaction of all debts due to him from and by his Maj said late father for his lodgings and other necessaries provided and employed in his said late father's services by writ date 15 August 1626 '.

${ }^{5}$ She had previously been married to Philip Morgan

${ }^{6}$ b. 1626 , Berkhampsted

${ }^{7}$ b. $1620 \mathrm{~s}$

${ }^{8}$ There were Standing Wardrobes at Windsor and Hampton Court and Removing Wardrobes that travelled with the monarch.

${ }^{9} 1628$ E115/363/551629 E115/380/123 1641E/115/86 21 Oct 1636 E/120/43742. This probably relates to a moated house at Woodcock Lodge Farm, Little Berkhampstead that belonged to the Smithsbys.

${ }^{10}$ Now at the Ashmolean Museum, Oxford. 
Chamber. Sir Richard eventually became a great grandfather of Oliver Cromwell, who on the deed of jointure at time of his marriage was called alias Williams. ${ }^{11}$ Many of Rabsy's contacts throughout her life had Cromwellian connections.

Presumably Rabsy grew up at Hampton Court with her brothers and sisters and in close contact with her uncle and cousins. Her uncle was Thomas Smithsby, who in the 1620s was Esquire Saddler to the King and was paid for 6 Bardelle saddles, ${ }^{12}$ and by 1640 was Under House Keeper of Hampton Court Palace, living at Palace Gate House 'built part with brick part with Timber and covered with Tile, situate upon or neer to the Greene commonly called Hampton Court Green, on the west syde of the way to the fery place'. ${ }^{13}$ Thomas, too, was taxed in the Royal Household and not in his previous area, London, where he was a citizen and Saddler; in 1640 he petitioned the King for payment of $£ 2,885126 \mathrm{~d}$ for goods and saddlery delivered to the Great Wardrobe. $^{14}$

He had married Martha Smith at St Dunstan's in the West on 29 January $1620^{15}$. Their children included Thomas junior, Sara,

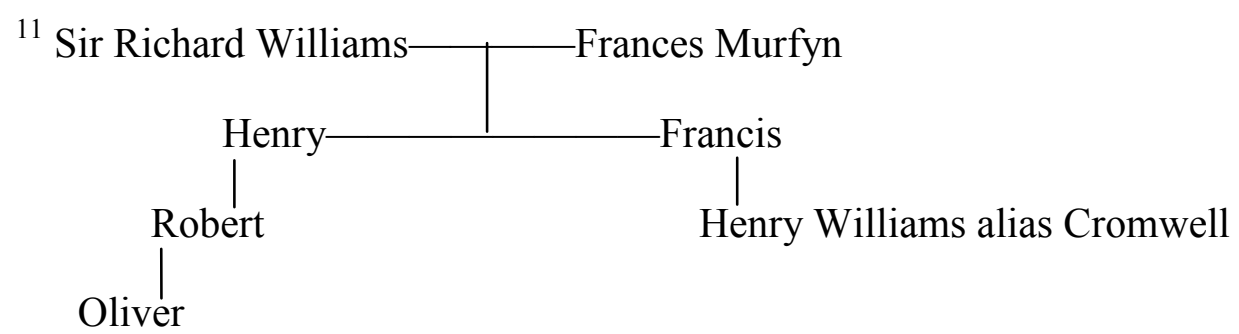

12 These were saddles used to accustom colts to the feel of a saddle-they were made in the form of a great saddle, but only of cloth stuffed with straw and no leather, wool or iron. Booke of stable warrantes PRO LC 5/7

${ }^{13}$ Ernest Law, The History of Hampton Court Palace (London, 1903), 265. In 1515 a wharf had been built to help with building Hampton Court, and houses for officials were built round the gate to the Palace.

14 Thomas was elected Master of the Saddlers Company on 14 August 1647, but unusually he refused to hold office.

15 She was the daughter of John Smith, cordwainer. 
Rebecca, Anne, Elizabeth, John and James. ${ }^{16}$ Thomas amassed considerable wealth, being involved in large transactions with Charles I. For example, in 1640 he lent the King $£ 10,000$ secured by the Farmers of the Customs. ${ }^{17}$ In 1644 he offered to make up the sum of $£ 5,469$ out of $£ 10,000$ required for the Kings service. The King's income came not out of current revenue, which had been used years in advance, but out of loans and advances which would not fall due for years to come. The customs were farmed to a group of men in return for a lump sum to the Exchequer, which gave the Government ready money which others had to collect. The farmers in the inner circle had tremendous resources, but they were joined by an outer circle of merchants and citizens like Thomas Smithsby who contributed to loans and often kept a deposit with a farmer to cover future custom dues. Clever merchants discovered that they could speculate by buying cheap assignments of all sorts of old debts. ${ }^{18}$ By 1654 farmers owed $£ 68,128$ by assignments and not less than $£ 10,651$ of this was owed to Thomas.

The Civil War affected the Smithsby family in various ways. William and Thomas's careers were dependent upon the Court but as the parliamentary army began to win battles they must have felt their relationship with Cromwell was an insurance policy against financial disaster and likely to be a help when their children grew older.

William Smithsby was still in charge of the Privy Lodgings when Charles I was seized by the army and entrusted to the

16 Thomas b 1629?; Sara daughter of T Smithsby baptised May 1632 St Dunstan in the West; Rebecca baptised 19 November 1633 St Dunstan in the West, m. Thomas Hartley, currier; John baptised 5 August 1635 St Dunstan in the West; Anne, m Hezekiah Haynes; James b 1646 ?

${ }^{17} 9$ November 1640 An Exchequer warrant to pay His Majesty’s saddler the interest of $£ 5,503810 \mathrm{~d}$.

18 W. Percy Harper, 'The Significance of the Farmers of the Customs in Public Finance in the Middle of the Seventeenth Century', Economica 25 (1929): 61-70, at 68: 'It is alleged that he hath by suits and other ways had from them about $£ 4,500$ in money' (citing British Museum, Stowe MS. 185, fo.17 et seq.). 
keeping of Col Whalley ${ }^{19}$ and his regiment at Hampton Court in 1647. Whalley, suspecting that the King had escaped, went to Smithsby, demanding to be taken to the Privy Lodgings, where he found that indeed the King had fled to the Isle of Wight. Smithsby had taken charge of royal jewels, miniatures and other small objects; he also hid a number of pictures which otherwise would have been disposed of by the Commonwealth but which he was able to hand over to Charles II at the Restoration.

He remained in charge at Hampton Court at the time of the King's execution and throughout the Commonwealth, but even though the Commonwealth Parliament was scrupulous in settling Royal bills and salaries, they were often years in arrears-'On Aug 101655 pay unto William Smithsby $£ 10334$ for salary of $£ 118$ for 2 years ended 5 March last and from thenceforth to continue the payment thereof unto him quarterly by equal portions'.

The royal goods were in his custody when the inventory was taken in 1649 at the start of a gigantic 3 year sale by the Commonwealth. ${ }^{20}$ His brother Thomas was still living in Palace Gate House and on 4 May 1652 Thomas and his wife were charged with having concealed hangings, beds and bedding, carpets, curtains and 4 pieces of old purple cloth belonging to Lord Cottington. Thomas pleaded that he held goods as security for a debt due from Lord Cottington and on 30 June was ordered to bring goods to Haberdashers Hall. On 22 July, information was given that the Smithsbys concealed these goods and kept them for own use. The case dragged on but on 28 September Thomas Smithsby was discharged as there was no proof of concealment.

19 Colonel Edward Whalley was a son of Frances Cromwell, aunt of Oliver Cromwell and second wife of Richard Whalley. Despite treating the King with courtesy, as a regicide he had to flee to Cambridge, Massachusetts after the Restoration, living there for sixteen years before his death.

${ }^{20}$ See Jennifer Potter, Strange Blooms: The Curious Lives and Adventures of the John Tradescants (London, 2006), ch. 18. 'One hawkeing glove of Henry ye Eighth sold for $2 \mathrm{~s} 0 \mathrm{~d}$ and six of his combe cases for $7 \mathrm{~s}$ '. 
He was still involved financially with whoever was in government. He had various dealings in London property over the years; for example, when the Duchess of Buckingham left her house and no longer had to pay for its upkeep the rental income had been assigned directly to Thomas Smithsby in late $1644 / 45 .^{21}$ The House of Commons Journal, 15 January 1649, shows £3,000 due owing to Thomas Smithsby. In 1653 the forfeited lands of John Carroll in Ireland were granted to Thomas Smithsby and Sir William Flower, both Protestants who had supported the English Commonwealth during the Irish confederate war. During the Commonwealth the Manor of Chelsea was seized among forfeited lands and was sold in 1654 by certain trustees appointed for that purpose, of whom Thomas was one, and put in trust for the coheirs of Duke of Hamilton. ${ }^{22}$ On 21 Feb 1654 a Warrant for payment of $£ 15,599$ to the Navy was signed by various people including, once again, Thomas Smithsby.

The Cromwellian side of the Smithsby family, for reasons that are not far to seek, gradually became more prominent. In 1642 Martha, Thomas's daughter, married as his second wife, John Blackwell senior (b. 1594/5), a wealthy London merchant, Grocer to the King, and a fervent Puritan. ${ }^{23}$ He and Martha had 8 children and a house at Mortlake. By 1650 he was owed $£ 2,798$ for groceries supplied to Charles I. Blackwell had a son, John (b. 1624), by his first wife, who with his father joined a Trained Band in the City to reinforce the Parliamentarian army-John senior as a captain and John junior as an ensign. John junior later joined the Parliamentarian army and fought at Naseby and

${ }^{21}$ See Philip McEvansoneya, 'The Sequestration and Dispersal of the Buckingham Collection', Journal of the History of Collections 8 (1986): 133-54.

22 Daniel Lysons, 'Chelsea: (part 1 of 3)', in The Environs of London: Volume 2, County of Middlesex (London, 1795), pp. 70-115. British History Online http://www.british-history.ac.uk/london-environs/vol2/pp70-115 [accessed 5 May 2017].

${ }^{23}$ Blackwell snr led a faction that broke up altar rails at St Thomas the Apostle, London. See Julie Spraggon, Puritan Iconoclasm during the English Civil War (Woodbridge, 2003), 139. 
Langport. He became Treasurer at War for Cromwell and tried to improve the payment to soldiers during the war. He was always close to the Smithsby family and married Elizabeth Smithsby (d. 1669), daughter of a James Smithsby, in $1647 .^{24}$

George, who had matriculated at Christ Church Oxford in 1647 aged $21,{ }^{25}$ became one of Cromwell's Life Guards and part of the Hispaniola expedition that captured Jamaica from the Spaniards. Oliver Cromwell had written to General Penn, 'I must commend also to you young Smithsby, who hath been of my life-guard. I believe him very stout, and one that takes great affection to the sea, and has been very much there of late. I pray you own him for my sake. He is my kinsman and if you have any employment that way, or which may fall, command him to it, as you shall judge him fit, and after you have seen his behaviour'. ${ }^{26}$ On 20 January 1656 George was appointed Captain.

Thomas junior ${ }^{27}$ enrolled at Inner Temple in June 1648 and became a Fellow of All Souls Oxford in $1648 .^{28}$ By the mid 1650s, he was Clerk of the Protector's Privy Seal. ${ }^{29}$ In September 1654, Thomas complained he was 'deprived of the priviledges and profits due to (them) equally as to other Master of Arts in the Colledge it is this day ordered (they) shall henceforth receave the same profits and privileges as other Master of Arts in the same

${ }^{24}$ One of their sons was Sir Lambert Blackwell, appointed Gentleman of the Privy Chamber in 1697, and knighted as envoy to Genoa in 1698.

${ }^{25} \mathrm{He}$ had been at school at Croydon, Surrey ( Mr Burton) and first matriculated at Sidney Sussex College Cambridge before migrating to Oxford

${ }^{26}$ See The Writings and Speeches of Oliver Cromwell, with elucidations by Thomas Carlyle, ed. Sophia C. Lomas, with an introduction by C. H. Firth (3 vols., London, 1904), iii, 456 (Supplement no. 94).

${ }^{27}$ Listed as son and heir apparent of Thomas Smithsby gentleman, armiger, from Hampton Court Middx

${ }^{28} \mathrm{He}$ was at St Johns Cambridge in 1646 when he was 17, and admitted to University College Oxford July 1648 (BA 1649 MA1651)

${ }^{29}$ Prior to 1307 the Privy Seal was kept by the Keeper of the Wardrobe. 
colledge in respect of dividends in the colledge or otherwise'. ${ }^{30}$ His brother John ${ }^{31}$ matriculated in 1650 and was Demy at Magdalen and BA 1653. He was told by order of the new visitors that he might stand as a candidate in the All Souls College elections in November 1653.

Thomas junior and John never achieved the careers they had hoped for. John Smithsby was buried on 5 April 1658 in the parish of Hampton. Thomas had died three years earlier in 1655, leaving a will in which he left to my intended wife Mistress Dorothie Kinnersley ${ }^{32}$ the sum of $£ 150$ pounds wch I desire may be bestowed on a necklace of pearls and a diamond locket and presented to her by my honourable father who I make my sole executor and my desire is he should hand it within one year after my decease and this - with the 3 rings and bracelet that I formerly gave her amount to about 200 pounds to my dear father the great diamond ring he gave me. to my brother John 2 hundred pounds with the interest due for the same upon the lands in Chelsey to my nephew John Blackwell fiftie pounds to my brother James my turkio stone ring to my niece Martha a piece of plate of tenne pounds on her marriage, to my good friend master Thompson tenne pounds for preaching my funeral sermon and to buy mourning to all my Fathers servants 40 s a piece and to my own servants $50 \mathrm{~s}$ a piece to Goody Silver $40 \mathrm{~s}$ - I give to my dear father the remainder'. 33

Dorothy's father Clement was another who managed to swing between the court and Cromwell. He had been one of Charles 1's most intimate servants in the Wardrobe but when the Commonwealth was trying in 1649 to sell the goods and personal

${ }^{30}$ The Register of the Visitors of The University of Oxford, from A.D. 1647-A.D. 1658, ed. Montagu Burrows (London, 1881), [for Aug 15 ${ }^{\text {th }}, 1650$ ], 307.

${ }^{31}$ Described as Gentleman from Hampton

32 Dorothy Kinnersley, daughter of Clement Kinnersley, was baptised 13 September 1634 in Wandsworth ; she eventually married John Betts 2 February 1658

${ }^{33}$ Prerogative Court of Canterbury Wills, vol. 8, 1657-1660 (London, 1936; British Record Society vol. 61), 627 
estate of the late King, he was one of the commissioners and contractors organising the sale to the best of advantage of the Commonwealth. However, like William Smithsby, he managed to smuggle out some of the Royal art treasures to be hidden by Royalist friends. Although the Palace and contents were put up for sale, only the furnishings were disposed of and the Palace failed to find a buyer - it was granted to Cromwell, who took up occupancy in 1654. By 1655 Kinnersley was His Highness' Wardrobe Keeper, responsible for the redecoration of Hampton Court, and like Cromwell, he preferred tapestries to paintings, which he felt were a poor man's substitute for a tapestry. Of the works of art withdrawn from sale worth $£ 35,497$, tapestries made up $£ 33,000$. $^{34}$ Cromwell died in $1658^{35}$ and at the Restoration Kinnersley was given three days to restore all the palaces for the King. He managed to raid the houses of Cromwell's widow and Richard Cromwell and reclaim a lot of ex-Royal treasures which, together with those that had been hidden by royalists, enabled him to make the palaces fit for a King. Kinnersley demanded $£ 7,000$ in back pay and claimed he had prevented $£ 500,000$ of the King's goods being sold. ${ }^{36}$

Thomas's daughter Elizabeth married Simon Middleton, son of Sir Hugh Middleton, goldsmith and founder of the New River Company and his daughter Anne married Hezekiah Haynes (1621-93), another Cromwellian, in 1653. ${ }^{37}$ Having emigrated with his family in 1633 to New England Haynes had returned in 1637 to the family home at Copford Hall, Essex, and stayed on to join the Parliamentary army. He became a Major-General,

34 Jerry Brotton, The Sale of the Late King's Goods: Charles I \& His Art Collection (London, 2007), 278.

${ }^{35}$ Kinnersley marched in Oliver Cromwell's funeral procession as Keeper of the Wardrobe at Whitehall.

${ }^{36} \mathrm{He}$ was Yeoman of the Removing Wardrobe from $1660-1662$ and helped by 2 grooms and 3 pages he looked after furnishings when Court moved palace to palace.

${ }^{37}$ His father was a devout Puritan who became Governor of Massachusetts and Connecticut. 
supervising Essex, Norfolk and Suffolk during the Commonwealth.

Apart from her two cousins, Rabsy also lost her parents and aunt and uncle within a few years in her late teens and twenties. William's wife Rabsey was buried on 6 December 1660 at St Mary Hampton and William, by then the late Keeper of the Kings Privy Lodgings, died on 2 December $1662 .{ }^{38}{ }^{39}$ Rabsy was left $£ 300$ in her father's will. ${ }^{40}$ Thomas' wife Martha died in 1656 and was buried at St Dunstan in the West on 6 May, followed by Thomas in $1658 .^{41}$

Various members of the family were involved with the events leading up to the Restoration. Both Blackwells had walked in Cromwell's funeral procession but in May 1659 a declaration to the former Speaker inviting members of the Long Parliament to return was delivered by Captain Blackwell and Major Haynes among others including Anthony Ashley Cooper, later to be Locke's employer. When the King was restored, Blackwell's career as military Treasurer ended; the Blackwells were excluded from pardon as regicides and had to restore the lands they had

${ }^{38}$ Calendar of Treasury Books vol $1160-167$

${ }^{39}$ Probate 11 July 1662 PROB/11/308/546

40 The will states 'that I William Smithsby of Hampton Court in the County of Middlesex Esq the thirteenth day of October in the year of our Lord 1660 This my last will and testament ---and bequeath to my son Richard S the sum of one hundred pounds and all my wearing apparel and do bequeath unto my d Ursula the wife of Christopher Barber the sum of 2200 Judith wife of Nightingale Hynd $£ 200$ Anne $£ 100$ should she be married to W Dickenson but if not $£ 300$

Martha $£ 300$

Mary $£ 300$

Rabsy $£ 300$

${ }^{41}$ His death was noted in the register of St John Hackney as dying on 6 Sept but being buried at St Dunstans on 23 September 1658. His will SWPT 458 in PCC Wooton 627 His executors were his two sons in law Hezekiah Haynes and Simon Middleton, and John Blackwell junior (by now MP for Surrey) was guardian of the younger children. 
acquired. ${ }^{42}$ They never received an official pardon and in 1662 were found guilty and given life imprisonment, a sentence which does not seem to have been enforced. Blackwell junior spent much time in Ireland where he had acquired property, but in 1669 he was back in London trying, with James Smithsby, Mary Smithsby, ${ }^{43}$ Simon Middleton and Rebecca Hartley ${ }^{44}$ to reclaim monies by means of a House of Lords petition from the farmers of customs in connection with a loan of $£ 10,000$ Thomas Smithsby had lent to the Crown in 1640. This was unsuccessful. ${ }^{45}$

In the 1660s Rabsy had dealings with Edward Backwell (1618-83), a goldsmith who also acted as a banker for a variety of people including the Queen. ${ }^{46} \mathrm{He}$ accepted money deposits returnable on demand - what was called running cash. Backwell's customers were Crown and government officials and merchants, and he also sold at a profit former Crown properties at Hampton Court, which may have been the origin of his connection with the Smithsbys. James Smithsby's name appears in the ledgers on his own account and when he is paid $£ 130$ by Rabsy:

$1668-1670$

Mrs Rabsey Smithsby

By balance from leger 2 Folio

Memo no part of this money to be paid

But upon endorsement on ye obligation

48713

${ }^{42}$ Blackwell senior had not been a judge at the King's trial but assisted with administration and had been paid $£ 1000$ by the Commons for expenses.

${ }^{43}$ She married Nathaniel Wickes in 1672.

${ }^{44}$ She married Thomas Hartley of the Curriers Company

45 In 1684 Blackwell went to Boston and tried to establish a chartered bank in Massachusetts, but this was short lived. Then in 1688 William Penn asked him to become Governor of Pennsylvania. He eventually returned to England and died at Bethnal Green in 1701.

${ }^{46}$ Backwell's ledgers are now a UNESCO Memory of the World (UK) as the oldest systematic set of banking records in the UK, a site in possession of the Royal Bank of Scotland. 
Mrs Rabsey Smithsby

To balance carried to leger S Folio

By balance from leger R Folio

588130

Memo no money to be paid but by endorsement on the obligation

By interest Accompt

58214104

Mrs Rabsey Smithsby

July $13 \quad 129$ for interest to the 2 instant

$P$ her self on from that

Time to pay $6 \mathrm{p}$ cent

11184

Nov $4 \quad 231 \quad$ To $4 \mathrm{~m}$ interest $\mathrm{p}$ herself

$212-$

Nov 4232 To Mr James Smithsby

$130 \quad 144104$

Mrs Rabsey Smithsby

Novem 281 By money at $51 / 2$ p cent 14

Memo no part of this money to be paid but by endorsement upon the obligation

James Smithsby also had account with Backwell:

Nov 281669

By 2 notes $£ 30 £ 20$

cr $\quad 50$

October 30

177 to his man

D 20

Novem 2

167 To William Foster

30

This bank account marks the start of a prosperous career. By 1674, when he was 28 and had married Mary Green (aged 23), ${ }^{47}$ James Smithsby (ca.1646-1691) was attached to the Royal Household as woollen draper in ordinary to Charles II and had become the man of business of Theophilus, $7^{\text {th }}$ Earl of Huntingdon (1655-1701). In 1677 he contributed to Charles' Act for raising money to build 30 ships of war. By 1682 he was paying Westminster rates in the alley in Russell St and in 1684 in St Martins Lane. On June 211687 he received $£ 469$ 9s for cloth furnished by him for the service of the Great Wardrobe in $1685 .^{48}$

${ }^{47}$ Spinster daughter of John Green, Recorder of London.

${ }^{48}$ See Leslie G. Matthews, 'Day Book of the Court Apothecary in the Time of William and Mary, 1691', Medical History 22, (1978): 161-73, at 168. Compare 163: 'In attendance on the Court or occupying administrative position in the Departments of 
The first extant letter between James and the Earl of Huntingdon is dated 20 January 1672/3 and mentions 'black cloath and patterns of druggetts, ${ }^{49}$ but soon the letters touch upon all aspects of Huntingdon's life; in 1674, Smithsby is sending down a dozen silver plates ${ }^{50}$ in 1676 , he is happy 'yr Lordshipp liked the candlesticks', ${ }^{51}$; public events are noted, and the Parliamentary programme is mentioned.

Once associated with Shaftesbury and Exclusion Bill, probably due to his fear of popery, Huntingdon was back as a Court supporter in 1681 and a member of Privy Council in 1683 . He was among those signing the order proclaiming James II king on 23 April 1685, and his wife was given a role serving Princess Anne while Huntingdon was made a Gentleman of the Bedchamber to her husband. In October 1688, the king authorised Huntingdon to raise Horse and Foot militia against invasion and in early November he joined the regiment in Plymouth. But large numbers started to desert to William of Orange and Huntingdon was taken prisoner by the Earl of Bath on 24 November.

James Smithsby was in constant correspondence with Huntingdon during this time, on 29 November 1688 writing that 'the Lord Churchill, the Duke of Grafton, Colonel Bartelott were gone on Sunday to the Prince of Orange and early Monday morning that Prince George and the Duke of Ormond were likewise gone, and not long after the Princess and Lady Churchill and Mrs Bartelott were missing and have not been heard of since, ${ }^{52}$ He attended a meeting between the King's Commissioners and the Prince of Orange in early December and wrote on 18 December passing on the intelligence he had gathered

State and to whom medicines were supplied [included] James Smithsby (supplier to or connected with the Great Wardrobe)'.

\footnotetext{
${ }^{49}$ Hastings family papers. Huntington Library MSS Dept. HA12421

${ }^{50}$ Huntington Library MS. HA12423

${ }^{51}$ Huntington Library MS. HA12425

${ }^{52}$ Huntington Library MS. HA12453
} 
On Sunday His Majtie returned to Whitehall since wch there has passed several expresses between him and the Prince of Orange and last night Marquess Halifax Earl of Shrewsbury and Lord de la Mare attended his Majtie from the Prince what their message was I cannot yet learne. The Prince his guards are at Whitehall and St James and His Majtie has removed out of towne to make room for the Princes troopes. His Majtie went about 11 oclock this day for Rochester which makes people $\mathrm{V}$ apprehensive that he designs for beyond there. ${ }^{53}$

Huntingdon's wife, exploiting her contacts with Princess Anne, worked hard in London to get him freed, but unfortunately died in childbirth on 24 December 1688 two days before he gained his freedom. Smithsby continued as his informant, writing on 6 August 1690 of 'news this day of the sailing of 3 ships loaded with ammunition and arms for Ireland and two others going richly loaded with persons of quality and goods. Later in the month I have paid My Lord Scarsdale 30 guineas on ye Ldsh pd bill I have received fifty pounds this week of the Ashby carrier'. ${ }^{5}$ Smithsby died in 1691.

When he died he left his two daughters $£ 6,000$ each while his wife had the lease of the house in St Martin in the Fields and his valuable New River share. He had also bought the freehold of Milkhouse Bridge, 27 acres NW of Bethnal Green. ${ }^{55}$

By the early 1680s Rabsy already must have been a close friend of John Locke, for in November 1683 a letter from Locke to Edward Clarke, ${ }^{56}$ dealing with the copies of Locke's politically

${ }^{53}$ Huntington Library MS. HA12457

${ }^{54}$ Huntington Library MS. HA12459

55 Margaret, who married Sir Francis Head, Baronet, at St Peter le Poer in May 1692, and Anne, who married Sir Hans Hamilton.

${ }^{56}$ Edward Clarke of Chipley 1650-1710, Member of Parliament for Taunton, 16901710, and member of the so-called 'College' with Locke and John Freke. Clarke had probably lodged in the rooms in Dorset Court before Locke took them over. For some of the aims and activities of the 'College', see Mark Knights, 'John Locke and Post- 
dangerous De Morbo Gallico - almost certainly a coded reference to some portion of his Two Treatises of Government-mentions that the 'chest that is now in Mrs --- custody was not opened'. ${ }^{57}$ There were two copies of the book (that is to say Two Treatises) by 1683 but one was halved and left with Mrs Smithsby and Clarke had orders to destroy the other copy if necessary. This copy, it seems, was destroyed and in 1686 Locke asked Edward Clarke to have the half which was with Rabsy moved elsewhere. On 25 November 1686, Clarke wrote to Locke:

These and all the rest of your cousins things that were moved to and from St Jones's are placed under the custody of Mrs R S who gives her hearty service to you in a house that her sister and she have taken near their former lodgings and are like to remain there with her as her own goods, until you order me otherwise to dispose of them. They are no manner of inconvenience or trouble other to the lady of the house and I believe will continue as safe there as anywhere in the town. ${ }^{58}$

While Locke was in Holland, Rabsy was number 9 in his list of cyphers, together with Edward Clarke at 3 and 13 and Robert Pawling at $8 .^{59}$

By this time Rabsy had begun a career as what would nowadays probably be called a personal shopper. In March 1688

Revolutionary Politics: Electoral Reform and the Franchise', Past and Present 213 (2011): 41-86.

57 The Correspondence of John Locke, ed. E. S. de Beer (8 vols., Oxford, 1976-) (henceforth Corr.), ii, 606.

${ }^{58}$ Corr., iii, 75. Rabsy's sister Anne never married William Dickenson because of his premature death and this is probably the reason the two sisters shared a home. Anne was executrix of his will as in 10 November 1680 there was a petition to the House of Lords about the will, where Rabsy Smithsby had sworn an affidavit: see HL/PO/JO/10/1/393/284 Smithsby v L C Justice Scroggs.

${ }^{59}$ Cypher for correspondence with Edward Clarke, [Autumn 1683?], in Corr., ii, 603-4. Robert Pawling, a mercer and gentleman from Oxford, had been responsible for the reception of Buckingham and Monmouth when they visited Oxford in 1680. In 1685 he had been arrested and sent to Oxford Castle at the time of Monmouth's invasion. In 1694 when duties were imposed on all legal documents he was appointed comptroller of the Stamp Office with a salary which eventually rose to $£ 300$. 
David Thomas joined Locke in Rotterdam and delivered things for his wardrobe purchased by Clarke and Rabsy: 'a good beaver hat made as high as the fashion will bear...a peruke very deep, the caul of a middle colour between black and flaxen' and 'a cloak of the best boiled chamlet'. ${ }^{60}$ On his return to England, Locke stayed as her lodger for a couple of years, and even after he moved to live at Oates with the Mashams she continued to buy clothes for him - in 1693 for example, gloves, 3 flannel shirts and 2 holland caps, and sometimes for things for Lady Masham on Locke's behalf - a parasol, a split bonigrace, ${ }^{61} 6$ pairs of gloves.

Mrs Smithsby also helped Edward Clarke with family shopping as Mary Clarke, who lived mainly in Somerset at Chipley, relied on her, 'her fancy and choice being so good in all things'. ${ }^{2}$ As Mary wrote to Edward, 'I am extremely obliged to you for the pains and trouble you take in buying those things we want which I know is a work very disagreeable to you but I hope Mrs Smithsby will give you what assistance she can'. ${ }^{63}$ From November 1694 onwards, she not only shopped for the Clarkes but sewed, presumably to augment her income. ${ }^{64}$ When Jack ${ }^{65}$ went to school she bought 20 ells ${ }^{66}$ of linen for two pairs of sheets and thirteen yards of huckaback ${ }^{67}$ for towels and table napkins and was paid 2/- for making them. In October 1696 Mary

${ }^{60}$ Locke to Mrs. Mary Clarke and to Edward Clarke, 28 February/9 March 1688, in Corr., iii, 388; Locke to Edward Clarke, [9/19 March 1688?], Corr., iii, 407.

${ }^{61}$ See $O E D$ : Bongrace, n. 1. A shade worn on the front of women's bonnets or caps to protect the complexion from the sun; 2 . A broad-brimmed hat fitted to shade the face.

${ }^{62}$ Mary Clarke to Edward Clarke 21 May 1687, SRO DD $\backslash S F / 7 / 1 / 31$

${ }^{63}$ Mary Clarke to Edward Clarke 27 January 1694/5, SRO DD $\backslash S F / 7 / 1 / 63$

${ }^{64}$ Underclothes were often made at home but some were made outside by women, in many cases widows needing charitable employment.

${ }^{65}$ John Clarke, 1685-1705, the Clarke's second son

${ }^{66}$ See $O E D$. Ell, n. 1. A measure of length. The English ell $=45$ inches.

${ }^{67}$ See $O E D$. Huckaback, n. a. A stout linen fabric, with weft threads thrown up alternately to form a rough surface. 
requested 'the black petticoat for Betty ${ }^{68}$ is to have a trimming on it such as Mrs Smithsby and you shall think fit according to the fashion'. When Anne, the second daughter, went to boarding school in Hackney, she was kitted out by Mrs Smithsby at a cost of $£ 18$ 5s $6 \mathrm{~d}$, and, later, Mrs Smithsby spent $£ 23$ 8s $11 \mathrm{~d}$ on school necessities for her, plus striped cambric, two quilted caps and a tower of hair, and a calico nightgown. ${ }^{69}$

Rabsy suffered another family loss in 1690 when her sister Maria died in Old Windsor, leaving 20s to the poor of Windsor and $20 \mathrm{~s}$ each to her sisters, Ann and Rabsy, and the rest to her brother in law and executor William Smith. ${ }^{70}$ Meanwhile she was still trying to get compensation for her father's arrears. In July 1696 she petitioned the Treasury, 'praying a grant of the small manors of Barton, Barrow, Goxhill and Hogsthorpe, County Lincoln for $99 \mathrm{yrs}$ at a small rent of $13 \mathrm{~s}$. $4 \mathrm{~d}$. in consideration of $12,000 l$. for 12 years' arrears due to her said father on an annuity of $1000 l$. granted by Charles II in 1661 out of the Customs'. ${ }^{71}$

Sylvester Brounower wrote to Locke from Whitehall on 24 April 1697, saying Mrs Smithsby 'would be glad to see you in Town again, as some in our Office do, she has been serv'd [i.e. treated] just as we are, for her Petition and the King's reference upon it, and Our Establishment with the King's reference upon it, are both, accidentally on purpose, lost in the Treasury'. ${ }^{72}$ She went on helping Locke until the end of his life, showing her continuing affectionate interest in him in her letters. On 10 July 1703, for instance, she told him:

${ }^{68}$ Elizabeth Clarke 1682-1712, the Clarke's eldest daughter.

${ }^{69}$ Bridget Clarke, 'Clothing the Family of an MP in the 1690s: An Analysis of the Day Book of Edward Clarke of Chipley, Somerset', Costume 43, (2009): 38-54.

${ }^{70}$ Will written in 1687 probate granted 1 Oct 1691

${ }^{71}$ Calendar of Treasury Books, vol. 11 (1696-97), 3 July.

${ }^{72}$ Sylvester Brounower to Locke, 24 April 1697, in Corr., v, 100-1. 
As you desired, I sent you six pounds of chocolate, which I hope you have received. I have made you six paire of new sleves, and put wrest bands and ruffles to the two paire you sent. I have allso bought you some wash Leather gloves, which I hope will Fitt, and you may Like, if you doe not, they may be returned and Changed for others. I have marked the new sleves with stiches of Crimson silke, that your servant may give them to you in paires.

\section{On 22 April 1704 Rabsy wrote again:}

yesterday I received from Mr Churchil, the bundle you mention, and will take Care to Observe your directions in what you desier in the Shirts and Caps. The papers I will give you account of as of the Former received from you. when I tell you tis impossible for me to expresse the satisfaction your favouer allwayes presents me with and the Joy I have in your health, though I cannot returne a suteable acknowledgment yet I can assure you I am Sir your affectt Friend and Faithfull Servant Rabsy Smithsby

\section{And again, on 7 August 1704,}

I then acquainted you there was thirty three yards of the Flanell you sent to me for shirts, and that there remained eight yards with me. As allso that...I received five pounds on a five pound Tickett of 1704. I will take Care to make up your Chocolate as soon as the weather is a little Coole for I observe it grinds best and finest then, and will marke it as you desire.

Locke died on 27 October 1704, but Rabsy soldiered on. After Edward Clarke's death in 1710 she received 'five pounds being for one years interest of one hundred pounds due Janry last on ye said Mr Clarke's personal bill dated 24 January 1686'. In 1714 she became a Queen's pensioner and was paid £20 per annum; she also received $£ 10$ of arrears. ${ }^{73}$ She had written her will on 10 July 1713 but lived on until $1720 .^{74}$

A Bank of England will extract tells us that Rabsy Smithsby, late of St James Westminster Spinster Dyed possessed of One

${ }^{73}$ See Calendar of Treasury Books, vol. 29, (1714-1715), 12 August 12 and 20 December.

\footnotetext{
${ }^{74}$ Probate was granted on 23 November 1720 to her nephew George Barber.
} 
Hundred and One Pounds Ten Shillings Lottery Annuity Stock and by her last will and testament dated the 10 day of July 1713 appointed the Lady Elizabeth Frankland, wife of $\mathrm{Sr}$ Tho. Frankland to be her sole executrix who has thereby (with consent of her Husband) a right to dispose of the said stock there being no particular mention or bequest thereof in the said will or codicil annext thereto dated 16 Aug $1717 . .^{75}$ The principal sum of $£ 400$ and the interest thereon she bequeathed 'to my nephew Capt George Barber'. A legacy of $£ 50$ went to Henry Frankland, great grandson of Oliver Cromwell and son of Sir Thomas Frankland, Baronet, ${ }^{76}$ and Mrs Anabell Russell was given 'what shall be borrowed for the arrears of the pension given me by Queen Mary'. She left Mrs Mary Russell, daughter of Brigadier Russell, $£ 50$ 'to be paid to her out of the money due to me on bondes from Edward Clarke Esq as soon as sufficient money shall have been received for payment of the same', and rings of 20s value to Mrs M Russell and Lady Frankland. Lady Frankland also received $£ 50$ and the remainder went to George Barber. A Codicil written on 6 August 1717 left $£ 50$ to Anne Barber.

Perhaps her life had seemed quiet and uneventful to her neighbours, but, as this biographical note has shown, actually Rabsy had an interesting life, on the periphery of exciting and dangerous events such as the execution of the King, the Restoration, Locke's exile and the Glorious Revolution and with interesting family connections. There must have been no shortage of subjects for discussion with her eminent lodger and correspondent, one of the foremost intellects of the age.

St John's Wood, London

${ }^{75}$ Proved in the Prerogative Court of Canterbury Wills 1713 - 1722 PROB 11576 in London the 23 day of November 1720 Registered this 29 day of July 1721.

${ }^{76}$ Sir Thomas Frankland (1665-1726) of Thirkleby Hall, Yorkshire. Member of Parliament. Married Elizabeth Russell, daughter of Sir John Russell and Frances Cromwell, daughter of Oliver Cromwell) in 1683 and they had 8 children. Henry made a fortune in the East India Company and became governor of Bengal. Frances Cromwell (born 1638) did not die until 27 January 1720, and so was roughly the same age as Rabsy. 